Lentera Pustaka 4 (1): 49-56, 2018

Copyright (C2018, ISSN: 2302-4666 print/ 2540-9638 online

Available Online at: http://ejournal.undip.ac.id/index.php/lpustaka

\title{
PERSEPSI PEMAKAI TERHADAP LAYANAN REPOSTTORI UPT PERPUSTAKAAN UNDIP
}

\author{
Sri Ati Suwanto ${ }^{1 *}$ \\ ${ }^{1}$ Program Studi Ilmu Perpustakaan, Fakultas Ilmu Budaya, Universitas Diponegoro, \\ Jl. Prof. Soedarto, SH, Kampus Undip Tembalang, Semarang, Indonesia \\ *)Korespondensi : tikasuwanto@gmail.com
}

\begin{abstract}
[User Perception of Undip Library Repository Services] This study discussed the user perceptions of the repository service at Diponegoro univeristy (Undip) Library Unit. The purpose of this study want to know how the user perceptions of the library service Undip repository. The research design used was qualitative with case study research. Data were collected using interviews, which were then analyzed descriptively. The subject of this research is UPT of Undip Library and its object is Repository Service of Undip. The informants were chosed by using purposive sampling, with the amount of 12 persons from 12 faculties. The research results could be seen that the user perceptions of the competence of the service manager repository both with the use of language that is easy, and quite simple. The access repository was stated quite easy and fast. User perceptions of the Undip web repository looked still monotonous, less varied in colors display. While the availability of the collection was limited and updating the collection was slow. This is the main cause of users' feeling that the Undip repository service had not been done optimally and the promotion din not affect the students especially in Undip understand this service. The resercher concluded that perceptions of human resource competency were considered competent, but were still considered inadequate. Besides, the human resources in each of the faculties had not been consistent in the development of the repository.
\end{abstract}

Key words $\quad$ : Users perception; Repository Service; UPT Undip Library

\begin{abstract}
Abstrak
Tujuan dari penelitian ini adalah menganalisis bagaimana persepsi pemakai terhadap layanan repositori UPT Perpustakaan Undip. Desain penelitian yang digunakan adalah kualitatif dengan jenis penelitian studi kasus. Pengumpulan data menggunakan wawancara, yang kemudian dianalisis secara deskriptif. Subyek penelitian ini adalah UPT Perpustakaan Undip dan objeknya Layanan Repositori Undip.Informan dipilih dengan menggunakan purposive sampling, sebanyak 12 orang dari 12 fakultas. Dari hasil penelitian dapat diketahui bahwa persepsi pemakai terhadap kompetensi pengelola layanan repositori baik dengan penggunaan bahasa yang mudah, dan cukup sederhana. Akses repositori dinyatakan cukup mudah dan cepat. Persepsi pemakai terhadap tampilan web repositori Undip dianggap masih monoton, kurang bervariasi dalam hal warna tampilan. Ketersediaan koleksi dinyatakan terbatas dan pembaharuan koleksi lambat. Hal ini yang menjadi penyebab utama pemakai merasa bahwa repositori Undip belum melakukan layanannya dengan optimal serta promosi yang kurang maksimal. Persepsi pemakai terhadap kompetensi SDM dinyatakan sudah kompeten, tetapi masih dianggap belum cukup. Disamping itu SDM di masing-masing fakutas belum konsisten dalam pengembangan repositori.
\end{abstract}

Kata kunci : Persepsi Pemakai; Layanan Repositori; UPT Perpustakaan Undip.

\section{Pendahuluan}

Perkembangan ilmu pengetahuan yang begitu pesat serasa tidak terbendung dan memberi dampak yang luar biasa bagi kehidupan manusia di segala aspek bidang kehidupan. Segala sesuatu terlihat begitu instan. Tuntutan mendapatkan sesuatu secara cepat, tepat, dan terjangkau oleh siapa pun 
menjadi gaya hidup masyarakat di era sekarang ini. Hal ini menjadi pemicu bagi para penyedia jasa layanan di bidang apapun untuk memenuhi tuntutan masyarakat tersebut jika ingin tetap exist bertahan.

Bidang pendidikan tidak luput dari tuntutan masyarakat era sekarang. Mengingat pendidikan menjadi salah satu bagian vital bagi bangsa Indonesia, maka penyedia pendidikan baik milik pemerintah maupun swasta, baik dalam bentuk sekolah, institut, ataupun lembaga, berlomba-lomba memberikan pelayanan yang terbaik guna memenenuhi tuntutan masyarakat. Perpustakaan merupakan salah satu aspek pendukung yang mendapat perhatian guna pemberian layanan yang terbaik.Hal ini dilakukan khususnya oleh sekolah-sekolah baik dari tingkat dasar sampai perguruan tinggi, baik sekolah negeri maupun swasta. Pencapaian terbaik masa depan dituangkan dalam sebuah visi yang diangkat tiap-tiap instansi.

Universitas Diponegoro merupakan salah satu universitas yang memiliki visi menjadi perguruan tinggi yang berorientasi penelitian (research college)pada tahun 2020. Guna menunjang pencapaian visi tersebut maka dibutuhkan sarana dan prasarana yang mendukung visi tersebut dan salah satunya adalah perpustakaan.

Perpustakaan merupakan unsur penunjang Universitas Diponegoro menuju research university tahun 2020. Dukungan dapat terlihat dari penyediaan layanan-layanan oleh perpustakaan bagi mahasiswa seperti layanan referensi dan layanan repositori.Hal ini dilakukan perpustakaan untuk memancing minat mahasiswa untuk melakukan penelitian.Namun, tampaknya harapan dari perpustakaan tidak selalu berjalan seperti kenyataan yang terjadi di lapangan karena layanan yang disediakan kurang dimanfaatkan secara optimal.Padahal layanan di perpustakaan telah dikembangkan dengan basis teknologi informasi dan komunikasi seperti yang tertulis dalam UU tentang Perpustakaan Nomor 43 Tahun 2007 Pasal 24 Ayat 3.

Layanan Repositori UPT Perpustakaan Undip berisi karya-karya ilmiah hasil dari civitasacademica Undip baik dosen-dosen maupun mahasiswa Undip yang berupa jurnal ilmiah, disertasi, tesis dan skripsi. Penyediaan layanan repositori diharapkan dapat menimbulkan keinginan khususnya mahasiswa untuk melakukan penelitian guna mencapai visi sebagai perguruan tinggi yang berorientasi penelitian (research college)tahun 2020.Akan tetapi, pada kenyataannya masih sedikit mahasiswa yang memanfaatkan layanan ini bahkan tidak sedikit mahasiswa yang tidak mengetahui adanya layanan repositori.Oleh karena itu terjadi ketimpangan antara penyediaan layanan repositori oleh UPT Perpustakaan Undip dengan pemanfaatannya. Oleh karena itu perlu dilakukan penelitian untuk mengetahui persepsi pemakai pada repository undip. Tujuan dilakukannya penelitian ini adalah untuk menganalisis persepsi pemakai terhadap layanan repositori di UPT Perpustakaan Undip. Persepsi pemakai sangat perlu diketahui karena dengan mengetahuinya UPT perpustakaan Undip 
dapat mengetahui kekurangannya kemudian meningkatkan layanannya, dalam hal ini khusunya Repository UNDIP ( Undip IR ).

Persepsi menurut pendapat James Gibson (2000) adalah proses pemberian arti bagi lingkungan oleh seorang individu. Oleh karena orang-orang memberi arti kepada stimulus, maka tiaptiap individu yang berbeda akan "melihat" barang yang sama dengan cara yang berbeda-beda. Karena persepsi itu bertautan dengan cara mendapatkan pengetahuan khusus tentang objek atau kejadian pada saat tertentu, maka persepsi terjadi kapan saja.

Rakhmat (2003), menyatakan bahwa faktor yang sangat berpengaruh bagi persepsi adalah faktor perhatian. Perhatian merupakan proses mental ketika stimulus menjadi menonjol dalam kesadaran ketika stimulus lainnya menurun atau melemah. Perhatian akan terjadi bila seseorang berkonsentrasi pada salah satu alat inderanya dan mengesampingkan masukan melalui indera yang lain. Dari uraian di atas dapat ditarik kesimpulan bahwa faktor yang mempengaruhi persepsi seseorang adalah faktor fungsional, faktor struktural, dan faktor perhatian.

Repositori dalam penelitian ini adalah repositori yang terdapat di UPT Perpustakaan Undip yag mengarah pada sebuah Institutional Repositori atau Simpanan Kelembagaan. Menurut Pendit (2008:137) pengertian Simpanan Kelembagaan merupakan sebuah kelembagaan yang memiliki kegiatan menghimpun dan melestarikan koleksi digital yang merupakan hasil karya intelektual dari sebuah komunitas tertentu. Dengan kata lain Simpanan Kelembagaan erat hubungannya dengan upaya menghimpun karya-karya intelektual sebuah perguruan tinggi. Karya-karya intelektual yang dihimpun kemudian banyak yang dikategorikan sebagai born digital atau terlahir dalam keadaan sudah digital.Persoalan yang dihadapi kemudian adalah hak cipta dan lisensi penggunanya karena dalam konteks ini Simpanan Kelembagaan merujuk ke upaya penyimpanan materi secara legal. Pendit (2008) memberi satu contoh konkret yang terjadi di lapangan untuk persoalan hak cipta dan kelembagaan legal yang dihadapi yaitu jika seorang dosen melakukan penelitian dan kemudian menandatangani perjanjian bahwa hasilnya akan menjadi milik universitas, maka hasil ini akan diletakkan di Simpanan Kelembagaan, sehingga untuk persoalan hak cipta dan kelembagaan legal dapat teratasi.

Berdasarkan uraian tersebut maka dapat disimpulkan bahwa layanan repositori adalah layanan yang menghimpun dan melestarikan koleksi digital hasil karya civitas akademika sebuah universitas.Karya yang dihimpun berupa skripsi, tesis, disertasi, jurnal atau karya ilmiah lainnya hasil karya dosen maupun mahasiswa sebuah universitas tertentu.

Istilah pemakai sama artinya dengan pemustaka. Dalam Kamus Perpustakaan dan Informasi pemakai perpustakaan diartikan sebagai kelompok orang dalam masyarakat yang secara intensif mengunjungi dan memakai layanan dan fasilitas perpustakaan (Sutarno, 2008:150). Berbeda makna 
dengan pengguna perpustakaan, yang menurut Sutarno (2008:156) pengguna perpustakaan adalah pengunjung, anggota dan pemakai perpustakaan.

Dalam Undang-Undang tentang Perpustakaan Nomor 43 Tahun 2007 Pasal 1 Ayat 9 didefinisikan bahwa pemakai adalah pengguna perpustakaan, yaitu perseorangan, kelompok orang, masyarakat, atau lembaga yang memanfaatkan fasilitas layanan perpustakaan. Dari uraian di atas maka dapat diambil kesimpulan bahwa pemakai adalah pengguna perpustakaan baik perseorangan atau kelompok yang memanfaatkan layanan dan koleksi perpustakaan.

\section{Metode Penelitian}

Desain penelitian yang digunakan desain penelitian kualitatif dan jenis penelitian studi kasus. Desain penelitian kualitatif digunakan untuk meneliti pada kondisi objek yang alamiah, dimana peneliti adalah sebagai instrumen kunci, teknik pengumpulan data dilakukan secara trianggulasi (gabungan), analisis data bersifat induktif dan hasil dari penelitian kualitatif lebih menekankan makna dari pada generalisasi (Sugiyono, 2005:1). Penelitian kualitatif menuntut peneliti dapat melampaui berbagai tahapan berpikir kritis-ilmiah, yang mana seorang peneliti kualitatif berpikir secara induktif, yaitu menangkap berbagai fakta atau fenomena sosial, melalui pengamatan di lapangan, kemudian menganalisisnya dan berupaya melakukan teorisasi berdasarkan apa yang diamati itu (Bungin, 2009:6).

Subjek dalam penelitian ini adalah mahasiswa Undip yang memanfaatkan layanan repositori UPT Perpustakaan Undip tidak termasuk Pasca Sarjana. Objek dalam penelitianini adalah layanan repositori UPT Perpustakaan Undip.

Cara pemilihan informan pada penelitian ini adalah dengan menggunakan pemilihan dengan tujuan (Purposive sampling) Menurut Herdiansyah (2011:106) Purposive sampling merupakan teknik non-probability sampling yang berdasarkan ciri-ciri yang dimiliki oleh subjek yang dipilih karena ciri-ciri tersebut sesuai dengan tujuan penelitian yang akan dilakukan. Peneliti menggunakan cara pengambilan purposive sampling karena dengan cara pengambilan sampel ini peneliti akan dapat memperoleh informan yang tepat, yaitu informan yang sudah pernah memanfaatkan layanan repositori UPT Perpustakaan Undip. Dalam penelitian ini informan yang diambil adalah informan yang telah mengetahui apa itu layanan repositori UPT Perpustakaan Undip dan informan yang minimal sudah pernah memanfaatkan layanan repositori UPT Perpustakaan Undip, karena dengan demikian informan telah memiliki persepsi tersendiri terhadap layanan repositori sehingga peneliti tidak kesulitan dalam melakukan pengumpulan data. Peneliti menggunakan dua belas informan dengan pertimbangan satu informan akan mewakili satu fakultas yang ada di Undip. Dengan demikian data yang terkumpul nantinya akan lebih menyeluruh dengan latar belakang dan ciri khas fakultas masing-masing dengan kata lain kekayaan informasi dapat terpenuhi. Peneliti juga mengambil satu 
informan kunci untuk memperkaya data dalam penelitian ini. Informan kunci yang diambil adalah orang yang sangat memahami repositori dari awal pembuatan sampai dengan yang sekarang. Informan kunci yang peneliti ambil adalah adalah penggagas dan pembuat web repositori sekaligus admin web IR Undip. Informan ini memberi keterangan perihal IR Undip mulai dari sejarah, cara kerja, sistem, kegiatan-kegiatan repositori dan lain sebagainya. Aktivitas penelitian tidak akan terlepas dari keberadaan data yang merupakan bahan baku informasi untuk memberikan gambaran spesifik mengenai obyek penelitian. Data adalah fakta empirik yang dikumpulkan oleh peneliti untuk kepentingan memecahkan masalah atau menjawab pertanyaan penelitian. Dalam penelitian ini mengunakan jenis data primer. Data primer adalah jenis data yang diperoleh secara langsung dari informan melalui wawancara. Teknik pengumpulan data yang digunakan oleh peneliti sebagai berikut: 1) Wawancara mendalam. Wawancara dilakukan secara kritis kepada sampel yang diambil sebagai informan. Peneliti menggunakan teknik wawancara semi terstruktur, dimana peneliti telah menyiapkan pertanyaan yang akan diajukan kepada informan atau sampel penelitian, tetapi pertanyaan yang telah disusun hanya sebagai patokan awal dalam wawancara, karena dari satu pertanyaan yang diajukan kepada informan atau sampel akan bisa timbul pertanyaan yang bisa mengarah pada informasi yang lebih mendalam mengenai persepsi pemakai terhadap layanan repositori UPT Perpustakaan Undip.

Peneliti menggali informasi yang mendalam untuk mendapatkan data tentang persepsi informan terhadap layanan repositori UPT Perpustakaan Undip. Pertanyaan penelitian yang ditanyakan seputar persepsi informan tentang Reability, Responsivioness, Competence, Access, Communication, Understanding/knowing the costumer, dan Reability. Dari pertanyaan tersebut kemudian dikembangkan dengan pertanyaan yang lebih mendalam kepada informan sampai data yang dibutuhkan terpenuhi.

Pengolahan data dilakukan berdasarkan teori Miles dan Huberman (dalam Herdiansyah, 2011), yang melalui empat tahapan yang harus dilakuka, yaitu :1) Pengumpulan data; 2) Reduksi Data; 3) Display Data; dan 4) Kesimpulan / Verifikasi

\section{Hasil penelitian.}

Dari hasil analisis data terhadap jawaban dari keseluruhan pertanyaan wawancara yang telah dilakukan peneliti terhadap informan, maka dapat menjawab rumusan masalah yaitu persepsi pemakai terhadap IR Undip secara garis besar sudah baik, tetapi masih ada beberapa informan yang menyatakan masih kurang baik. Secara rinci dpat peneliti simpulkan :

Persepsi terhadap tingkat kemudahan dalam menemukan informasi di IR Undip beberapa informan menyatakan kurang baik. Mereka mendapat kesulitan ketika pencarian dilakukan dari sisi subyek. Hal ini dimungkinkan karena belum dilakukan pengelompokan yang lebih spesifik, yang ada 
baru dilakukan pada tingkat general. Dari beberapa kelemahan yang ada. Bisa jadi sekaligus juga menjadi peluang potensi yang dapat dikembangkan. Antara lain, ada beragam alat bantu untuk menemukan informasi, baik dari lingkup Fakultar, Jurusan, Program Studi maupun Subyek. Meskipun untuk membuat ideal ragam tersebut membutuhkan pembenahan yang lebih teliti kembali.

Kemudahan menemukan informasi dari fitur-fitur di website, mempunyai variasi jawaban, mulai dari sangat mudah, mudah, cukup mudah serta tidak mudah.Secara garis besar dapat dikatakan bahwa ada kecenderungan mudah untuk menemukan informasi, terutma kalau dikaitkan dengankeberadaan Program Studi dan Jurusan yang ada.Pada elemen fitur tampaknya mempunyai peluang membantu pencarian informasi, hal yang mnyebabkan biasanya karena tingkat kemudahan pencarian yang sangat tunggi.

Persepsi informan terhadap kemudahan akses IR Undip, beberapa dari mereka menyatakan kurang puas terhadap akses repositori di luar UPT Perpustakaan Undip. Mereka merasa kesulitan akses karena sinyalnya kecil. Untuk mengatasi itu sebagian informan mengatakan lebih senang akses dari dalam gedung UPT Perpustakaan Undip.

Tentang SDM, persepsi informan terhadap konsistensi kerja pustakawan dalam mengelola $I R$ Undip menyatakan kurang puas. Pustakawan dianggap masih kurang konsistensi kerjanya, sehingga koleksi repositori yang kurang lengkap dan kurang mutakhir. Jika dilihat dari web yang sudah berjalan sampai sekarang, informan menilai bahwa web sudah siap memberikan layanan repositori. Artinya informan percaya bahwa web repositori sudah siap memberikan layanan kepada informan dan pemakai yang lainnya tetapi pustakawan/ pengelola repositori kurang konsisten mengerjakan bagiannya.

Persepsi informan terhadap kebutuhan informasi di repositori masih kurang. Hal ini dinyatakan oleh informan bahwa kebutuhan informasi yang mereka perlukan tidak sepenuhnya tersedia, dan update data yang lambat dirasa menjadi penghambat tidak tersedianya informasi yang dibutuhkan informan.

Persepsi informan terhadap kompetensi SDM pengelola repositori dinyatakan bahwa SDM sudah kompeten dalam pengelolaan repositori, artinya SDM sudah ahli dan mengerti untuk mengupdate koleksi terbaru atau upload data terbaru, mengklasifikasikan informasi berdasarkan tahun dan subjek, dan pengelolaan yang lainnya.

Persepsi pemakai terhadap kemudahan yang dirasakan ketika mengakses IR Undip adalah akses pencarian IR Undip tidak sulit dan tidak berbelit - belit, cukup sederhana. Informan merasakan bahwa IR Undip memiliki kecepatan akses yang baik.

Persepsi pemakai terhadap pemakaian bahasa dalam pengaksesan IR Undip menyatakan bahwa bahasa yang digunakan sangat sederhana sehingga mudah dipahami.Pengelompokkan koleksi berdasarkan fakultas, tahun koleksi dibuat, subjek koleksi dan tipe koleksi mempermudah informan menemukan informasi yang dicari. 
Persepsi pemakai terhadap repositori Undip dalam pemenuhan kebutuhaninformasi masih kurang karena informasi yang disajikan masih sangat terbatas dan tidak up to date. Koleksi yang terbaru masih banyak yang belum dilayankan atau di-upload. Ada satu keunggulan dari repositori Undip yang dirasakan pemakai memenuhi kebutuhan pemakai yaitu karya ilmiah yang dilayankan dapat di-download full text tanpa harus login id.

\section{Simpulan}

Dari hasil penelitian dapat disimpulkan bahwa persepsi pemakai terhadap kompetensi SDM dinyatakan sudah kompeten, tetapi masih dianggap belum cukup memadai. Disamping itu SDM di masing-masing fakutas belum konsisten dalam pengembangan repositori. Secara rinci persepsi pemakai terhadap kompetensi pengelola layanan repositori dinyatakan baik dengan penggunaan bahasa yang mudah, dan cukup sederhana. Akses repositori dinyatakan cukup mudah dan cepat. Persepsi pemakai terhadap tampilan web repositori Undip dianggap masih monoton, kurang bervariasi dalam hal warna tampilan. Ketersediaan koleksi dinyatakan terbatas dan pembaharuan koleksi lambat. Hal ini yang menjadi penyebab utama pemakai merasa bahwa repositori Undip belum melakukan layanannya dengan optimal serta promosi yang kurang maksimal.

Berdasarkan hasil analisis data terhadap jawaban wawancara yang telah dilakukan peneliti terhadap informan, maka ada beberapa saran yang dapat diambil untuk meningkatkan kinerja repositori Undip. Berikut saran dari hasil wawancara ; Masalah kinerja SDM yang tidak konsisten sebaiknya ada kesepakatan bersama hitam di atas putih. Jadi pengelola repositori di masing -masing fakultas diikat dengan kesepakatan yang di dalamnya berisi tata tertib peraturan untuk mengembangkan repositori. Promosi sebaiknya dilakukan secara terus - menerus lewat sosial media, mading - mading kampus, web Undip dan media lainnya secara berkala. Serta dibutuhkan peran semua pihak termasuk dosen untuk mengarahkan mahasiswa memanfaatkan repositori Undip. Repositori Undip perlu dibuatkan FB dan twitter khusus untuk sosialisasi. Kerjasama antar staf administrasi fakultas dan administrasi universitas sebaiknya lebih ditingkatkan dengan cara sering diadakan meeting guna membahas pengembangan repositori Undip serta pengevaluasian kinerja masing - masing admin.

\section{Daftar Pustaka}

Ali, Abdullah. 2007. Sosiologi Pendidikan dan Dakwah. Cirebon: Stain Press

Arikunto, Suharsini. 1998. Prosedur Penelitian: Suatu Pendekatan Praktek. Jakarta: Rineka Cipta

Atmanta, Ignasius Tri Sunarna. 2010. "Persepsi Pengguna terhadap Desain Interior Perpustakaan di Perpustakaan Universitas Atma Jaya Yogyakarta”. Skripsi. Yogyakarta: Universitas Atma Jaya 
Aulianti, Ika Lutfi. 2010. "Persepsi Pemustaka terhadap Layanan Deposit di Perpustakaan Jawa Tengah”. Skripsi. Semarang: Universitas Diponegoro

Bungin, Burhan. 2009. Penelitian Kualitatif. Jakarta: Kencana.

Danim, Sudarwan. 2004. Metode Penelitian untuk Ilmu-ilmu Perilaku: Acuan Dasar bagi Mahasiswa Program Sarjana dan Peneliti Pemula. Jakarta: Bumi Aksara

Herdiansyah, Haris. 2011. Metodologi Penelitian Kualitatif untuk Ilmu-Ilmu Sosial. Jakarta: Salemba Humanika.

Nawawi, Hadari. 1993. Metode Penelitian Bidang Sosial. Yogyakarta: Gadjah Mada University Press.

Pendit, Putu Laxman. 2008. Perpustakaan Digital dari A sampai Z. Jakarta: Citra Karyakarsa Mandiri.

Rahmawati, Nanik. 2008. "Persepsi Masyarakat terhadap Keberadaan: Study tentang Perpustakaan Daerah Yogyakarta”. Thesis. Yogyakarta: Universitas Gajah Mada

Rakhmat, Jalaluddin. 2003. Psikologi Komunikasi. Bandung: Remaja Rosdakarya

Sobur, Alex. 2003. Psikologi Umum. Bandung: Pustaka Setia

Sugiyono. 2005. Memahami Penelitian Kualitatif. Bandung: Alfabeta.

Sulistyo-Basuki. 2010. Metode Penelitian. Jakarta: Penaku

Sutarno NS. 2008. KamusPerpustakaan dan Informasi. Jakarta: Jala Permata

Tim Penyusun Kamus Pusat Bahasa. 2001. Kamus Besar Bahasa Indonesia. Jakarta: Balai Pustaka

Utomo, Putut Joko. 2001. "Persepsi Mahasiswa Terhadap Kualitas Layanan Di Perpustakaan Fakultas Ilmu Sosial dan Ilmu Politik Unversitas Sebelas Maret”. Skripsi. Surakarta: Universitas Sebelas Maret

Warsito, Hermawan. 1992. Pengantar Metodologi Penelitian.Jakarta : Gramedia Pustaka Utama

Wiranto, FA. 2008. Perpustakaan dalam Dinamika Pendidikan dan Kemasyarakatan. Semarang: Universitas Katolik Soegijapranata

. 2008. Metode Penelitian. Surabaya. Universitas Kristen Petra, Jumat 18 November2011.http://digilib.petra.ac.id/ 